\title{
TEACHING READING USING TALKING STICK
}

\author{
Siti Khodijah ${ }^{1}$, Labibah ${ }^{2}$ \\ ${ }^{1}$ IKIP Siliwangi \\ ${ }^{2}$ IKIP Siliwangi \\ 12vitri3199@gmail.com , 2labibahtanubrata@gmail.com
}

\begin{abstract}
Language is the most important aspect in human interaction. People communicate and interact with other using the language. In global community, English has become an international language that is used by many people around the world. Reading is one of English language skills and it is one of the ways to learn English. Reading activity should get more attention. It is because there are many students who get some difficulties in understanding a text. In this research inform the using of talking stick in teaching reading. The objective of this research was to find out whether there was any significant difference in improvement the reading ability of recount text of the tenth grade students of SMK Rosma Karawang in academic year 2018/2019 by using talking stick method. The method used was quantitative method. In this research the writer used pre-experimental design of one group pretest and posttest. The data were analyzed by using paired sample test and processed by using SPSS 23 for windows. The results of the research showed there was significant increase of student's reading ability.
\end{abstract}

Keywords: Teaching, Reading, Talking Stick

\section{INTRODUCTION}

Reading is considered one of the most important skills that students of English as a Second Language need to acquire. It is in line with the statement of Campbell (1995cited in Aryana and Apsari, 2018) that reading is the most is useful skill for foreign language learners since a reading skill mastery is the key for a successfull academic life, a widen horizon, and an access to new knowledge and information. Therefore, getting students to read English texts is an important part of the English teacher's job because of four reasons. First, many students want and need to be able to read English texts for present study, for further study, for future career or simply for pleasure. Second, reading is very useful for language acquisition. Third, reading texts provide good models for English writing concerning construction of phrases, sentences, paragraph, and whole texts. Finally, good reading texts can introduce interesting topics, stimulate discussion, excite creative responses, and provide the springboard for well-rounded, fascinating lessons (Harmer, 2007, cited in Apsari, 2014).

According to Parmawati and Yugafiati (2017), one of the purposes of teaching English as a foreign language to Indonesian people is that they can read, grasp the idea, and understand the book written in English. According to Nunan (2003), "reading is a fluent process of readers combining information from a text and their own background knowledge to building meaning". Reading can not be separated from daily activities. People read many kinds written materials such as newspapers, magazines, novels, academic books and so on. Through reading people can get a lot of information, knowledge, enjoyment and even problem solution. 
Reading can be defined in many ways; it depends on the one who will give the definition. Cline, Johnstone, \& King (2006) state that reading is decoding and understanding text for particular reader purposes. Reader decodes written text by translating text to speech, and translating directly to meaning. To understand written text, reader engagein constructive processes to make text meaningful, which is the end goal or product. Weaver (2009) argues that reading is a processvery much determined by what the reader's brain and emotions and beliefs bring to the reading: the knowledge/information (or misinformation, absence of information), strategies for processing text, moods fears and joys.

However, reading has complicated problem. It is supported by many research results (Hamra, 1993 and 1996; Mardiana, 1993; Kweldju 2001 cited in Syatriana, 2010, as cited in Apsari and yana, 2015) indicated that the ability of Indonesian students to read English texts was very low. To solve the problem, the reseacher uses a method to improve students' reading skill. It is expected that The Talking Stick Method can help the students' to understand the text easily, and make them active and creative in reading. According to Sani (2015), talking stick method is a method in the learning process by stick, student who gets a stick must answer the question by the teacher. This method gives an alternative manner to refresh and learning process in a more enjoyable way. The talking stick method is also a kind of ways to makes the teacher more creative and responsible. Teacher becomes more serious in teaching and the learning process well prepared. This method creates an ideal condition because teacher explains the materials by fun learning activities in classes.

Talking stick is a kind of methods in language teaching used to invite all the people speak and extend their opinions in an ethnic group meeting. For long times ago, Indian ethnics are used their method as a good wise facilitation without talking side each others. Talking stick is used by the councils to decide who will have the right to speak up. When the leader starts in discussion, he must hold the stick. Then, the stick moves to another person who wants to speak or respond the topic. After all the people have the opportunities to convey their opinions, the stick returnable to the leader. According to Sani (2015), talking stick method is a method in the learning process by a stick, student who gets the stick must answer the question by the teacher. The talking stick method is one of innovative strategies in order to make the students speak up and express their idea confidently.

Based on description above the writer interested in conducting research title "Teaching Reading Using Talking Stick" at The Tenth Grade Students of SMK Rosma Karawang in the academic year of 2018/2019.

\section{METHOD}

In this research, the researcher used the quantitative method Allen, Earl, (2011) define that quantitative method are "emphasizes the production of precise and generalizable statistical findings and are generally more appropriate to nomothetic aims."In this research, the writer used one group pretest and posttest design. The sample of the research took one class of second-year students in class X AP 1 which consisted of 30 students only girls. In this research, the writer used the test as an instrument of the research. In collecting the data the writer used a test which included a pretest and posttest, pretest conducted on January 17th and posttest conducted on February 7th, 2018. The writer used the statistic calculation of Ttest Formula to analyzed the data. The calculation using SPSS 23 for windows. The writer used a normality test, the homogeneity test, and paired sample test. 


\section{RESULTS AND DISCUSSION}

\section{Results}

The data obtained through the tests. The pre-test was conducted on January, $17^{\text {th }} 2018$. The results of the pretest were intended to find out the students' capability in reading before they were treated. Posttest was given on February, $7^{\text {th }}$ 2018. The following were the results of means of pretest and posttest.

Table 1. Score of Pretest and Posttest

\begin{tabular}{|c|c|c|c|}
\hline $\begin{array}{l}\text { Students } \\
\text { Number }\end{array}$ & Pre Test & Post Test & $\begin{array}{c}\text { Gaine } \\
\text { d }\end{array}$ \\
\hline Student 1 & 68 & 76 & 8 \\
\hline Student 2 & 56 & 88 & 32 \\
\hline Student 3 & 64 & 84 & 20 \\
\hline Student 4 & 72 & 84 & 12 \\
\hline Student 5 & 68 & 84 & 16 \\
\hline Student 6 & 60 & 80 & 20 \\
\hline Student 7 & 72 & 88 & 16 \\
\hline Student 8 & 68 & 84 & 16 \\
\hline Student 9 & 68 & 80 & 12 \\
\hline Student 10 & 48 & 72 & 24 \\
\hline Student 11 & 56 & 76 & 20 \\
\hline Student 12 & 64 & 80 & 16 \\
\hline Student 13 & 72 & 92 & 20 \\
\hline Student 14 & 68 & 80 & 12 \\
\hline Student 15 & 60 & 80 & 20 \\
\hline Student 16 & 60 & 76 & 16 \\
\hline Student 17 & 60 & 80 & 20 \\
\hline Student 18 & 64 & 88 & 24 \\
\hline Student 19 & 64 & 80 & 16 \\
\hline Student 20 & 72 & 76 & 4 \\
\hline Student 21 & 52 & 88 & 36 \\
\hline Student 22 & 68 & 80 & 12 \\
\hline Student 23 & 64 & 72 & 8 \\
\hline Student 24 & 56 & 84 & 28 \\
\hline Student 25 & 68 & 76 & 8 \\
\hline Student 26 & 64 & 80 & 16 \\
\hline Student 27 & 64 & 76 & 12 \\
\hline Student 28 & 56 & 84 & 28 \\
\hline Student 29 & 64 & 84 & 20 \\
\hline Student 30 & 80 & 92 & 12 \\
\hline Total & 1.920 & 2.444 & 524 \\
\hline Mean & 64.00 & 81.46 & \\
\hline
\end{tabular}


From the table above, of the result pretest and posttest score, it shows that the mean of pretest is 64.00 the highest score is 80 and the lowest score is 60 . The KKM score at SMK Rosma Karawang is 70 . And after the writer giving the treatment using talking stick that the mean of posttest is 81.46 the highest score is 92 and the lowest score is 72 . Then the gained score is 524 .

Table 2. Test Normality

\begin{tabular}{|c|c|c|c|c|c|c|}
\hline \multirow{2}{*}{} & \multicolumn{3}{|c|}{ Kolmogorov-Smirnova } & \multicolumn{3}{c|}{ Shapiro-Wilk } \\
\cline { 2 - 7 } & $\begin{array}{c}\text { Statisti } \\
\mathrm{c}\end{array}$ & Df & Sig. & $\begin{array}{c}\text { Statisti } \\
\mathrm{c}\end{array}$ & Df & Sig. \\
\hline PRETEST &, 167 & 30 &, 033 &, 962 & 30 &, 350 \\
POSTTEST &, 176 & 30 &, 019 &, 943 & 30 &, 107 \\
\hline
\end{tabular}

Based on table 2, the writer used to test normality from Kolmogorov-Smirnova because the samples are 30 students. If the samples of students under than 30 , the writer used test normality from Shapiro-Wilk. On the table showed that statistic of pretest is 0.167 and statistic of posttest is 0.176 with Df is 30 . The significant value of pretest is 0.033 higher than $0.05(0.033>0.05)$ and significant value of posttest is 0.019 higher than 0.05 $(0.109>0.05)$. It means the data is the normality distribution.

Table 3. Test Homogeneity

\begin{tabular}{|c|c|c|c|}
\hline $\begin{array}{r}\text { Levene } \\
\text { Statistic }\end{array}$ & $\begin{array}{c}\mathrm{df} \\
1\end{array}$ & $\begin{array}{c}\mathrm{df} \\
2\end{array}$ & Sig. \\
\hline, 573 & 1 & 58 & $\begin{array}{l}, 45 \\
2\end{array}$ \\
\hline
\end{tabular}

Based on table 3, the data is homogeneity distribution that significant value was 0.452 higher than $0.05(0.452>0.05)$ with levene statistic 0.573 and $\mathrm{df} 1$ is 1 , then $\mathrm{df} 2$ is 58 .

Table 4. Paired Samples Test

\begin{tabular}{|c|c|c|c|c|c|c|c|c|}
\hline & \multicolumn{5}{|c|}{ Paired Differences } & \multirow{3}{*}{$\mathrm{T}$} & \multirow{3}{*}{$\mathrm{df}$} & \multirow{3}{*}{$\begin{array}{l}\text { Sig. }(2 \\
\text { tailed) }\end{array}$} \\
\hline & \multirow[t]{2}{*}{ Mean } & \multirow[t]{2}{*}{$\begin{array}{c}\text { Std. } \\
\text { Deviati } \\
\text { o n }\end{array}$} & \multirow{2}{*}{$\begin{array}{l}\text { Std. } \\
\text { Error } \\
\text { Mea } \\
\mathrm{n}\end{array}$} & \multicolumn{2}{|c|}{$\begin{array}{c}95 \% \\
\text { Confidence } \\
\text { Interval of the } \\
\text { Difference }\end{array}$} & & & \\
\hline & & & & Lower & Upper & & & \\
\hline $\begin{array}{cc}\text { Pair 1 } & \text { PRETES } \\
& \mathrm{T} \\
& - \\
& \text { POSTTE } \\
& \text { S T }\end{array}$ & $-17,467$ & 7,314 & 1,355 & $\begin{array}{l}- \\
20,19 \\
8\end{array}$ & $\begin{array}{l}- \\
14,73 \\
5\end{array}$ & $-13,080$ & 29 &, 000 \\
\hline
\end{tabular}


Based on table 4, the mean is -17.467 and the standard deviation is 7.314 , then standard error mean is 1.355 . The lower and upper confidence interval of differences are -20.198 and -14.735 and $\mathrm{T}$ is -13.080 , then $\mathrm{df}$ is 29 . The Sig (2-tailed) $0.000<0.05$ it can be stated that there was a significant difference in the students' reading mastery ability by using a talking stick method.

\section{Discussion}

Based on the previous chapter, the objective of this research is to find out whether or not using a talking stick method can improve students ability in teaching reading mastery. Based on statistical computation, the research used SPSS V.23 to calculate the data to find out the score of normality test, homogeneity test, and paired samples test. The significant value of pretest was 0.033 and it was higher than $0.05(0.033>0.05)$ means that the data is normality distribution. Then, for the significant value of posttest was 0.109 and it was higher than $0.05(0.019>0.05)$ it means that data is normality distribution. Then, for the test of homogeneity, the significant value was 0.452 , it means the significant $0.452>0.05$ so, the data is homogeneity distributed. From the data analysis above, the researcher concluded that the talking stick method can improve the students' ability in teaching reading.

\section{CONCLUSION}

From the analysis data in chapter four, the researcher finds that after the implementation of the method, the students reading mastery can be improved. Based on the students' response, talking stick is interesting and exciting. They enjoyable and participate in learning process. This conclusion describe before and after taught by using talking stick. It can be seen, significance value (.00) was lower than the significance level (.05). Pretest and posttest score, the mean of the posttest is higher than pretest $(81.46>64.00)$. It indicates there was an improvement of students' achievement of English class. It can be concluded that teaching students' using talking stick method was effective to improve the students' ability in reading mastery

\section{ACKNOWLEDGMENTS}

The writer thank to Ganesha, S.pd the teacher subject of english in SMK Rosma and Mr Widodo the principal of SMK Rosma Karawang who insight permission to did the research in SMK Rosma Karawang. We would like to express my grattitude to our lecture Trisnendri Syahrizal M.pd and Dr. Irma Savitri Sadikin M.pd for guiding our throughout the journal project, and to carry out the projet. And we would to thank to all those who help the journal.

\section{REFERENCES}

Allen Rubin;Earl R Babbie. (2011). Research methods for social work. Belmont, CA : Brooks/Cole Cengage.

Apsari, Y. (2014). The Use Of Authentic Materials In Teaching Reading Comprehension. ELTIN JOURNAL, Journal of English Language Teaching in Indonesia, 2(2).

Apsari, Y., \& Yana, Y. (2015). Teachers'techniques And Problems In Teaching Reading. P2M STKIP Siliwangi, 2(2), 217-233.

Aryana, S., \& Apsari, Y. (2018). Analysing Teacher's Difficulties In Teaching Listening. Eltin Journal, Journal of English Language Teaching in Indonesia, 6(2), 100-106. 
Brown, H. D. (2000). Principle of Language Learning and Teaching. London: Longman Publishing Group.

Cline, F., Johnstone, C., \& King, T. (2006). Focus group recreations to three definitions of reading (as originally develoved in support of NARAP goal 1). Minneapolis: National Accessible Reading Assessment.

Nunan, D. (2003). Practical Engish Language Teaching. Singapore: McGraw Hill.

Nuttal, C. E. (1982). Teaching Reading Skill in A Foreign Language. London: Heinemann Educational Books.

Parmawati, A., \& Yugafiati, R. (2017). Using Authentic Material To Improve Students'reading Interest (A Classroom Action Research in the Second Semester Students of STKIP Siliwangi Bandung). ELTIN JOURNAL, Journal of English Language Teaching in Indonesia, 5(1), 1-8.

Sani, I. K. and B. (2015). Ragam Pengembangan Model Pembelajaran. Yogyakarta: Kata Pena.

Weaver, C. (2009). Reading Process: Brief Edition of Reading Process and Practice. Ohio: Miami University, Oxford. 